stance on ecological issues and seeking to conserve energy resources' amounted to a necessity for this purpose. The chancellor rejected EH's argument that the proposals would have a significant negative impact on the appearance of the church. The proposals would have an impact, 'but not a disastrous one' and the proposals were not irreversible. As to the third of the Bishopsgate questions, the chancellor said that he was persuaded that the proposals 'do not do as great damage' as had been suggested and that the plans were 'sound and well thought out'. The grant of planning permission was not determinative but it was persuasive. A faculty was granted subject to conditions. [Alexander McGregor]

doi:10.1017/So956618X11000640

\author{
St Michael and All Angels, Withyham \\ Chichester Consistory Court: Hill Ch, April 2011 \\ Sale of paintings - redundancy
}

The minister and churchwardens of the parish sought a faculty for the sale of a set of four fourteenth-century Italian paintings that had been gifted to the church in 1849 . The paintings were provisionally valued at between $£^{1}$ million and $f_{1.5}$ million and had been housed at a museum for 14 years. There was little meaningful connection between the paintings and the parish, they were not currently in use and nor was there any realistic prospect of them returning to the church. The sale was commended by both the diocesan advisory committee and the Church Buildings Council. The chancellor summarised the law as expounded in Re St Peter, Draycott [2009] Fam 93, acknowledged that the burden of proof rested on the petitioners and recognised the above factors militating in favour of a faculty. Although there was no dire financial emergency within the parish, the parish only covered its annual expenditure each year by digging progressively more deeply into it reserves. The faculty was granted. [RA]

doi:10.1017/So956618X11000652

\title{
Re St Michael, Tilehurst
}

Oxford Consistory Court: Bursell Ch, April 2011

Deceased infant - teddy-bear-shaped memorial - pastoral considerations

The petitioner, whose child had died aged six months, sought a faculty permitting the introduction of a memorial, the central section of which would incorporate a detailed teddy bear embracing its top and side. The grave was situated in a part of the churchyard primarily used for children's and babies' burials. A number of memorials that did not comply with the churchyard regulations 